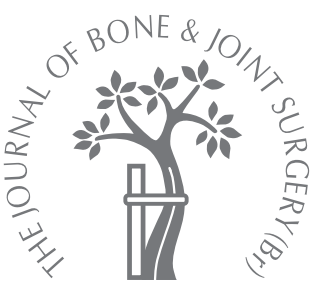

\title{
Fractures of the odontoid in children with an open basilar synchondrosis
}

H. S. Hosalkar, J. N. Greenbaum, J. M. Flynn, D. B. Cameron, J. P. Dormans, D. S. Drummond

From the Children's Hospital of Philadelphia, Philadelphia, USA

H. S. Hosalkar, MD, MBMS(Orth), FCPS(Orth), DNB(Orth), Clinical Instructor University of Pennsylvania School of Medicine, 2nd Floor Silverstein, 3400 Spruce Street, Philadelphia, Pennsylvania 19104, USA.

J. N. Greenbaum, MD, MBA, Resident

Harvard Medical School, 25 Shattuck Street, Boston, Massachusetts 02115, USA.

In. M. Flynn, MD, Associate Professor

D. B. Cameron, BA, Research Co-ordinator

J. P. Dormans, MD, Professor Department of Orthopaedic Surgery

D. S. Drummond, MD, Emeritus Chief, Professor Division of Orthopaedic Surgery

Children's Hospital of Philadelphia, 2nd floor, Wood building, 34th Civic Center Boulevard, Philadelphia, Pennsylvania 19104, USA.

Correspondence should be sent to $\mathrm{Dr} \mathrm{H}$. S. Hosalkar; e-mail: Harish.hosalkar@uphs.upenn. edu

(C)2009 British Editorial Society of Bone and Joint Surgery doi:10.1302/0301-620X.91B6. $22173 \$ 2.00$

$J$ Bone Joint Surg $[\mathrm{Br}]$ 2009;91-B:789-96. Received 9 December 2008; Accepted after revision 26 February 2009

\begin{abstract}
Fractures of the odontoid in children with an open basilar synchondrosis differ from those which occur in older children and adults. We have reviewed the morphology of these fractures and present a classification system for them.

There were four distinct patterns of fracture (types IA to IC and type II) which were distinguished by the site of the fracture, the degree of displacement and the presence or absence of atlantoaxial dislocation. Children with a closed synchondrosis were classified using the system devised by Anderson and D'Alonzo. Those with an open synchondrosis had a comparatively lower incidence of traumatic brain injury, a higher rate of missed diagnosis and a shorter mean stay in hospital. Certain subtypes (type IA and type II) are likely to be missed on plain radiographs and therefore more advanced imaging is recommended. We suggest staged treatment with initial stabilisation in a Halo body jacket and early fusion for those with unstable injuries, severe displacement or neurological involvement.
\end{abstract}

It has been estimated that the prevalence of cervical spinal injuries in children is 7.5 cases per 100000 individuals. ${ }^{1}$ Approximately $75 \%$ of these are fractures ${ }^{1}$ and in younger children they are more likely to occur in the upper cervical region and fractures of the odontoid are the most common. ${ }^{1}$ The synchondroses of the axis remain open until approximately seven years of age and are at risk of fracture, even from a relatively low-energy injury. Thus, fractures of the odontoid process in children with an open synchondrosis are distinct from those observed in older children with a closed synchondrosis and from those in adults.

Unlike those seen in adults, odontoid fractures in young children do not usually occur through bone at the base of the dens, but as a separation of the cartilaginous plate of the basilar or dentocentral synchondrosis between the dens and the body of the axis. ${ }^{2,3}$ Prompt diagnosis and treatment are important because delay can lead to serious complications including neurological deterioration ${ }^{4}$ and nonunion. ${ }^{5-10}$

Since 1951 , at least 110 cases of odontoid fracture, also known as traumatic epiphysiolysis ${ }^{11}$ or synchondritic slip, ${ }^{12}$ have been reported in children. Most of these are individual case reports or part of larger series including adults. ${ }^{1,5,9,13,14}$ There are few large series $^{9,15,16}$ which focus on children and a number of important issues remain unre- solved. First, there is no classification system for these fractures in children. ${ }^{10}$ Secondly, although there have been reports of associated injury to the spinal cord and traumatic brain injury, there are no studies with sufficient numbers of children from which to draw meaningful conclusions. ${ }^{9,17}$ The role of advanced imaging including CT and MRI needs to be determined. Finally, a study comparing the outcome of odontoid fracture in the child with an unossified basilar synchondrosis with that of the child with an ossified synchondrosis has not been undertaken.

Our aims in this study therefore were as follows: 1) to study fractures of the odontoid in children with an emphasis on those with an open basilar synchondrosis; 2) to compare the data with those of a series of children with a closed basilar synchondrosis; and 3) to develop a useful working classification for fractures of the odontoid in childhood.

\section{Patients and Methods}

After obtaining approval from our Institutional Review Board, we identified all the children whom we had treated for fractures of the odontoid using the relevant ICD-9 codes $^{18}$ between 1986 and 2003. We retrospectively reviewed the available records and imaging studies for these patients. Each patient was followed from initial presentation to the present 
Table I. Clinical details of the 17 patients with open basilar synchondrosis

\begin{tabular}{|c|c|c|c|c|c|c|c|c|c|c|c|c|}
\hline Case & Gender & $\begin{array}{l}\text { Age } \\
\text { (yrs) }\end{array}$ & $\begin{array}{l}\text { Delay } \\
\text { diagnosis } \\
\text { (days) }\end{array}$ & $\begin{array}{l}\text { Patient delay } \\
\text { or missed. } \\
\text { diagnosis }\end{array}$ & $\begin{array}{l}\text { Glasgow } \\
\text { coma scale }^{27}\end{array}$ & $\begin{array}{l}\text { Mechanism of } \\
7 \text { injury }\end{array}$ & $\begin{array}{l}\text { Neck pain } \\
\text { or TTP }\end{array}$ & $\begin{array}{l}\text { Range of } \\
\text { movement } \\
\text { symptoms }\end{array}$ & $\begin{array}{l}\text { Spinal- } \\
\text { cord injury }\end{array}$ & $\begin{array}{l}\text { Brain } \\
\text { injury }\end{array}$ & $\begin{array}{l}\text { Fracture } \\
\text { type }\end{array}$ & $\begin{array}{l}\text { Other fractures } \\
\text { and/or } \\
\text { dislocations and/ } \\
\text { or congenital } \\
\text { cervical spinal } \\
\text { abnormalities }\end{array}$ \\
\hline 1 & $\mathrm{M}$ & 3.35 & 0 & & 15 & $\begin{array}{l}\text { Sports } \\
\text { (wrestling } \\
\text { with brother, } \\
\text { slammed on } \\
\text { back) }\end{array}$ & Yes & Yes & No & No & IA & $\begin{array}{l}\text { Congenital } \\
\text { absence of pos- } \\
\text { terior arch of } \mathrm{C} 1\end{array}$ \\
\hline 2 & $\mathrm{~F}$ & 2.33 & 2 & Patient & 15 & Abuse & Yes & Yes & No & No & IA & None \\
\hline 3 & $\mathrm{~F}$ & 3.23 & 7 & Missed & 15 & $\begin{array}{l}\text { Fall ( } 25 \text { feet } \\
\text { from } 2 \text { nd } \\
\text { storey } \\
\text { window) }\end{array}$ & Yes & No & No & No & IA & None \\
\hline 4 & $\mathrm{~F}$ & 3.89 & 5 & Missed & 15 & $\begin{array}{l}\text { Fall (less than } \\
5 \text { feet) }\end{array}$ & Yes & No & No & No & IA & $\begin{array}{l}\text { Congenital } \\
\text { hypoplasia of } \\
\text { posterior } \\
\text { elements and } \\
\text { wedging of } \\
\text { bodies of C } \\
\text { and C5 }\end{array}$ \\
\hline 5 & $\mathrm{M}$ & 5.05 & 0 & & 15 & $\begin{array}{l}\text { Sports (biking } \\
\text { no } \\
\text { helmet) }\end{array}$ & Yes & Yes & No & No & IB & None \\
\hline 6 & $\mathrm{~F}$ & 5.18 & 0 & & 15 & $\begin{array}{l}\text { Motor-vehicle } \\
\text { accident } \\
\text { (restraint) }\end{array}$ & Yes & No & No & No & IB & None \\
\hline 7 & $\mathrm{~F}$ & 3.87 & 0 & & 15 & $\begin{array}{l}\text { Fall (less than } \\
5 \text { feet } \\
\text { from porch) }\end{array}$ & Yes & Yes & No & No & IB & None \\
\hline 8 & $\mathrm{~F}$ & 5.15 & 0 & & 15 & $\begin{array}{l}\text { Fall (less than } \\
5 \text { feet) }\end{array}$ & Yes & No & No & No & IB & $\begin{array}{l}\text { Left basilar skull } \\
\text { fracture }\end{array}$ \\
\hline 9 & $\mathrm{M}$ & 6.69 & 1 & Patient & 15 & $\begin{array}{l}\text { Sports (tackled } \\
\text { playing } \\
\text { football) }\end{array}$ & Yes & Yes & No & No & IB & None \\
\hline 10 & $\mathrm{~F}$ & 1.98 & 4 & Missed & 15 & $\begin{array}{l}\text { Motor-vehicle } \\
\text { accident } \\
\text { (restrained) }\end{array}$ & Yes & Yes & No & No & IB & None \\
\hline 11 & $\mathrm{M}$ & 1.46 & 30 & Patient & 14 & Abuse & Yes & Yes & No & No & IB & $\begin{array}{l}\text { T10 } \\
\text { compression } \\
\text { fracture }\end{array}$ \\
\hline 12 & $\mathrm{~F}$ & 2.66 & 0 & & 15 & $\begin{array}{l}\text { Motor-vehicle } \\
\text { accident (front } \\
\text { facing } \\
\text { car seat) }\end{array}$ & Yes & No & No & No & IB & None \\
\hline 13 & $\mathrm{~F}$ & 1.85 & 0 & & Coma & $\begin{array}{l}\text { Motor-vehicle } \\
\text { accident } \\
\text { (restrained) }\end{array}$ & $N / A^{\S}$ & $N / A$ & $\begin{array}{l}\text { Quadri- } \\
\text { plegia }\end{array}$ & $\begin{array}{l}\text { Intraventricular } \\
\text { haemorrhage }\end{array}$ & IC & $\begin{array}{l}\text { Left clavicle } \\
\text { fracture } \\
\text { complete C1-2 } \\
\text { dislocation }\end{array}$ \\
\hline 14 & $\mathrm{~F}$ & 1.28 & 0 & & 3 & $\begin{array}{l}\text { Motor-vehicle } \\
\text { accident (front } \\
\text { facing car seat) }\end{array}$ & N/A & $N / A$ & $\begin{array}{l}\text { Quadri- } \\
\text { plegia }\end{array}$ & $\begin{array}{l}\text { Hypoxic ischaemic } \\
\text { encephalopathy }\end{array}$ & IC & $\begin{array}{l}\text { Complete C1-2 } \\
\text { dislocation }\end{array}$ \\
\hline 15 & $\mathrm{~F}$ & 6.44 & 0 & & 9 & $\begin{array}{l}\text { Pedestrian vs } \\
\text { car }\end{array}$ & Yes & No & No & $\begin{array}{l}\text { Concussion and } \\
\text { post-concussion } \\
\text { syndrome }\end{array}$ & II & None \\
\hline 16 & $\mathrm{M}$ & 3.04 & 0 & & 15 & $\begin{array}{l}\text { Other (kicked } \\
\text { in head by } \\
\text { farm animal) }\end{array}$ & Yes & No & No & No & II & $\begin{array}{l}\text { Depressed skull } \\
\text { fracture }\end{array}$ \\
\hline 17 & $\mathrm{M}$ & 3.30 & 0 & Missed & 15 & $\begin{array}{l}\text { Fall (from bunk } \\
\text { bed) }\end{array}$ & $\begin{array}{l}\text { Yes } \\
\text { (anterior) }\end{array}$ & Yes & No & No & II & $\begin{array}{l}\text { Congenital } \\
\text { fusions of } \mathrm{C} 2-3 \\
\text { and } \mathrm{C} 6-7\end{array}$ \\
\hline
\end{tabular}

* patient delay: failed to present immediately after trauma; missed diagnosis: physician failed to diagnose odontoid fracture

† TTP, tenderness to palpation

¥ either stiff neck, torticollis, patient unwilling to rotate neck, or patient holding head

$\S \mathrm{N} / \mathrm{A}$, not available

time unless they had been lost to follow-up. We included all patients with clinical and radiological data sufficient to confirm the diagnosis, location and stability of the injury, and its clinical outcome.
Those with an open synchondrosis were placed in one group and older children with a closed synchondrosis were placed in another. We recorded age, gender, the mechanism and pattern of the injury, any delay in diagnosis (> 24 hours 
Table II. Details of treatment and outcome in the 17 patients with an open basilar synchondrosis

\begin{tabular}{|c|c|c|c|c|c|}
\hline Case & Initial treatment & Duration of admission (days) & Complications & Outcome & Follow-up (yrs) \\
\hline \multirow[t]{2}{*}{1} & \multirow[t]{2}{*}{ Halo } & \multirow[t]{2}{*}{8} & $\begin{array}{l}\text { 1) loosening of pins following a } \\
\text { fall requiring halo re-application }\end{array}$ & \multirow[t]{2}{*}{ Healed } & \multirow[t]{2}{*}{7.2} \\
\hline & & & 2) pin infection & & \\
\hline 2 & Minerva & 21 & None & Healed & 2.4 \\
\hline 3 & Halo & 8 & Loosening of pin & Healed & 1.3 \\
\hline 4 & Halo & 4 & Pin infection & Healed & 1.3 \\
\hline 5 & Halo & 7 & None & Healed & 1.9 \\
\hline 6 & Halo & 6 & None & Healed & 1.3 \\
\hline 7 & Minerva & 7 & None & Healed & 1.5 \\
\hline 8 & Halo & 5 & None & Healed & 1.8 \\
\hline \multirow[t]{2}{*}{9} & \multirow[t]{2}{*}{ Halo } & \multirow[t]{2}{*}{9} & $\begin{array}{l}\text { 1) loosening of } 3 \text { pins requiring } \\
\text { halo re-application }\end{array}$ & \multirow[t]{2}{*}{ Healed } & \multirow[t]{2}{*}{1.6} \\
\hline & & & 2) pin infection & & \\
\hline 10 & Minerva & 5 & $\begin{array}{l}\text { Allergic contact dermatitis with } \\
2 \text { casts requiring cast removal } \\
\text { and treatment with traction }\end{array}$ & Healed & 3.6 \\
\hline 11 & Minerva & 8 & None & Healed & 1.3 \\
\hline \multirow[t]{2}{*}{12} & \multirow[t]{2}{*}{$\begin{array}{l}\text { Minerva (patient } 17 \\
\text { initially placed in traction) }\end{array}$} & 17 & \multirow{2}{*}{\multicolumn{2}{|c|}{$\begin{array}{l}\text { 1) continued anterior subluxation Healed } \\
\text { requiring chin strap } \\
\text { 2) skin infection }\end{array}$}} & 2.7 \\
\hline & & & & & \\
\hline \multirow[t]{2}{*}{13} & \multirow[t]{2}{*}{ Halo } & \multirow[t]{2}{*}{18} & $\begin{array}{l}\text { 1) halo dislodgement leading to } \\
\text { loss of reduction and halo } \\
\text { re-application }\end{array}$ & \multirow[t]{2}{*}{$\begin{array}{l}\text { Posterior C1-2 fusion for continued } \\
\text { instability; solid fusion eventually } \\
\text { achieved }\end{array}$} & \multirow[t]{2}{*}{2.1} \\
\hline & & & 2) nonunion & & \\
\hline 14 & None & 4 & $N / A^{*}$ & Died day 4 & N/A \\
\hline 15 & Halo & 12 & Halo dislodgement & Healed & 1.5 \\
\hline 16 & Minerva & 9 & None & No displacement & $\begin{array}{l}\text { Lost to follow- } \\
\text { up after } 6 \text { years }\end{array}$ \\
\hline 17 & Minerva & $<24$ hrs & None & Healed & 5.1 \\
\hline
\end{tabular}

* N/A, not available

Table III. Clinical details of the six patients with a closed basilar synchondrosis

\begin{tabular}{|c|c|c|c|c|c|c|c|c|c|c|}
\hline Case & Gender & $\begin{array}{l}\text { Age } \\
\text { (yrs) }\end{array}$ & $\begin{array}{l}\text { Glasgow } \\
\text { coma } \\
\text { scale }^{27}\end{array}$ & $\begin{array}{l}\text { Mechanism of } \\
\text { injury }\end{array}$ & $\begin{array}{l}\text { Neck } \\
\text { pain } \\
\text { or TTP* }\end{array}$ & $\begin{array}{l}\text { Range of movement } \\
\text { symptoms }^{\dagger}\end{array}$ & $\begin{array}{l}\text { Spinal-cord } \\
\text { injury }\end{array}$ & Brain injury & $\begin{array}{l}\text { Fracture } \\
\text { type }\end{array}$ & $\begin{array}{l}\text { Other fractures and/or } \\
\text { dislocations and/or } \\
\text { congenital cervical spinal } \\
\text { abnormalities }\end{array}$ \\
\hline 1 & $\mathrm{~F}$ & 10.70 & 15 & $\begin{array}{l}\text { Sports (ran into } \\
\text { wall during } \\
\text { 'wallball') }\end{array}$ & Yes & No & No & $\begin{array}{l}\text { Left frontal epidural } \\
\text { haematoma }\end{array}$ & II & $\begin{array}{l}\text { Supraorbital and Salter II } \\
\text { middle finger fractures }\end{array}$ \\
\hline 2 & M & 13.60 & 6 & $\begin{array}{l}\text { Pedestrian vs } \\
\text { car }\end{array}$ & $\mathrm{N} / \mathrm{A}^{\ddagger}$ & $\mathrm{N} / \mathrm{A}$ & No & $\begin{array}{l}\text { Closed head trauma } \\
\text { with increased } \\
\text { intracranialpressure }\end{array}$ & II & $\begin{array}{l}\text { Basilar skull open tibia- } \\
\text { fibula, Salter-Harris II } \\
\text { distal femur, R scapula, } \\
\text { L olecranon, and } \\
\text { L acetabular fractures }\end{array}$ \\
\hline 3 & $\mathrm{~F}$ & 14.52 & 6 & $\begin{array}{l}\text { Motor-vehicle } \\
\text { accident } \\
\text { (unrestrained) }\end{array}$ & $\mathrm{N} / \mathrm{A}$ & $\mathrm{N} / \mathrm{A}$ & No & Intraparenchymal & II & $\begin{array}{l}\mathrm{L} \text { frontal sinus and left } \\
\text { orbit fractures }\end{array}$ \\
\hline 4 & M & 14.39 & 15 & $\begin{array}{l}\text { Scooter vs car } \\
\text { (no helmet) }\end{array}$ & Yes & No & No & No & III & $\begin{array}{l}R \text { first distal phalanx } \\
\text { fractures }\end{array}$ \\
\hline 5 & $\mathrm{~F}$ & 15.89 & 15 & $\begin{array}{l}\text { Motor-vehicle } \\
\text { accident }\end{array}$ & Yes & No & No & No & III & None \\
\hline 6 & M & 12.33 & 15 & $\begin{array}{l}\text { Motor-vehicle } \\
\text { accident }\end{array}$ & Yes & Yes & No & No & III & $L$ front tooth fracture \\
\hline
\end{tabular}

* TTP, tenderness to palpation

$\dagger$ either stiff neck, torticollis, patient unwilling to rotate neck, or patient holding head

‡N/A, not available 
H. S. HOSALKAR, J. N. GREENBAUM, J. M. FLYNN, D. B. CAMERON, J. P. DORMANS, D. S. DRUMMOND

Table IV. Details of treatment and outcome in six patients with closed basilar synchondrosis

\begin{tabular}{|c|c|c|c|c|c|}
\hline Case & Initial treatment & $\begin{array}{l}\text { Duration of admission } \\
\text { (days) }\end{array}$ & Complications & Outcome & $\begin{array}{l}\text { Follow-up } \\
\text { (yrs) }\end{array}$ \\
\hline \multirow[t]{2}{*}{1} & Halo & 7 & None & Healed & 1.93 \\
\hline & & & & $\begin{array}{l}\text { Posterior }{ }^{*} 1-2 \text { fusion for continued } \\
\text { instability }{ }^{*} \text { fusion }\end{array}$ & \\
\hline 2 & Halo & 58 & Continued instability & Stable & 2.00 \\
\hline \multirow[t]{2}{*}{3} & Halo & 7 & 1) Halo re-application & $\begin{array}{l}\text { Posterior C1-2 fusion for continued } \\
\text { instability }^{*} \text {; fusion }\end{array}$ & 1.80 \\
\hline & & & 2) Continued instability & Stable & \\
\hline 4 & Halo & 10 & Pin infection & Healed & 1.80 \\
\hline 5 & Halo & 7 & Pin infection & Healed & 2.18 \\
\hline 6 & Hard cervical collar & 9 & None & Healed & 2.90 \\
\hline
\end{tabular}
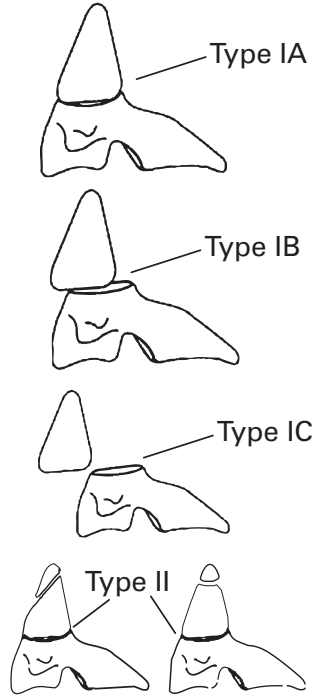

Fig. 1

Diagrams showing the classification of odontoid fractures.

after injury), the clinical and neurological presentation, management and outcome.

We identified 23 patients who met our inclusion criteria who had been treated at our hospital. There were 17 children under the age of seven years ( 6 boys, 11 girls) and six (3 boys, 3 girls) aged seven years or over. The clinical details and outcome of these patients are summarised in Tables I to IV.

The fractures were described according to: 1) age and presence or absence of a fused synchondrosis; 2) the anatomical level of the fracture at (I) or proximal to (II) the synchondrosis; and 3) the degree of displacement at the level of fracture $(<10 \%$ (A), $10 \%$ to $100 \%$ (B), > $100 \%$ (C)). The percentage displacement was obtained as a ratio by dividing the maximum displacement of the fractured odonoid process (distance from the cortex of the odontoid to the outer cortex of the body of C2) by the anteroposterior diameter of the odontoid. In each case healing of the fracture was assessed by plain lateral flexion and extension radiographs of the cervical spine.

Statistical analysis. Fisher's exact test for non-parametric data was used to identify differences between the group of younger patients with an unossified basilar synchondrosis and the older patients with a closed synchondrosis. Also, we used Student's $t$-test for parametric data and Fisher's exact test to measure any differences between non-parametric data from younger patients with different types of fracture. A $\mathrm{p}$-value $\leq 0.05$ was considered to be statistically significant.

\section{Results}

Patients with an open basilar synchondrosis. In the group with an open synchondrosis, there were 17 patients with a mean age of 3.6 years (1.3 to 6.7). The mechanisms of injury differed considerably and are described in Table I. There was a delay in diagnosis of more than one day in six of the 17 patients $(35 \%)$; the mean delay was eight days (2 to 30 ). The diagnosis was missed by a medical professional in four patients. In the other three there was a parental delay in seeking treatment.

Only four of the 17 patients were initially seen at our hospital; 13 were referred from elsewhere. Neck pain or tenderness was found in 13 of the 15 patients who were conscious on presentation (two were unconscious). A torticollis-like deformity or neck stiffness with reduction in the range of movement was seen in eight. Two (cases 13 and 14) had an associated injury to the spinal cord with quadriplegia. Both children were less than two years old and had a complete C1-2 dissociation with an odontoid fracture (atlanto-axial fracture-dislocation). They had also sustained brain injuries with intraventricular haemorrhage and hypoxic ischaemic encephalopathy. One (case 13) sustained an injury at the cervicomedullary junction and 


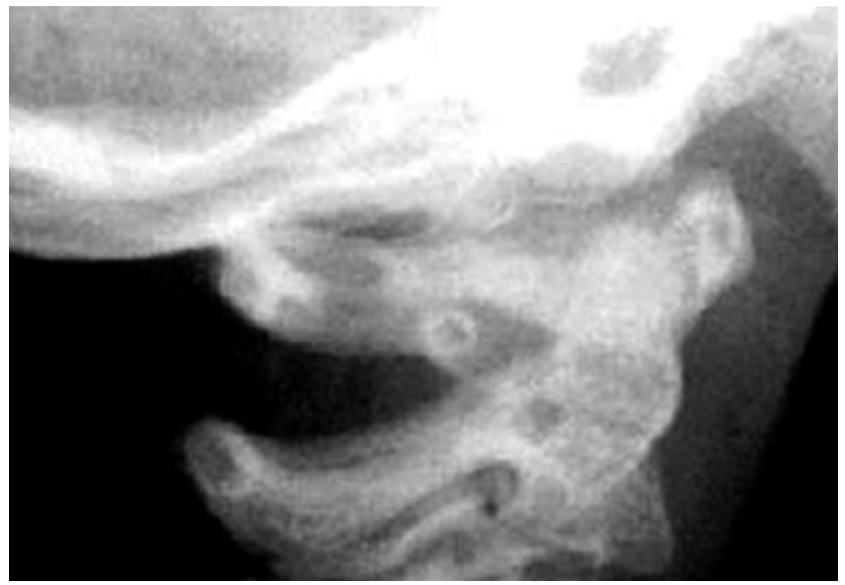

Fig. 2a

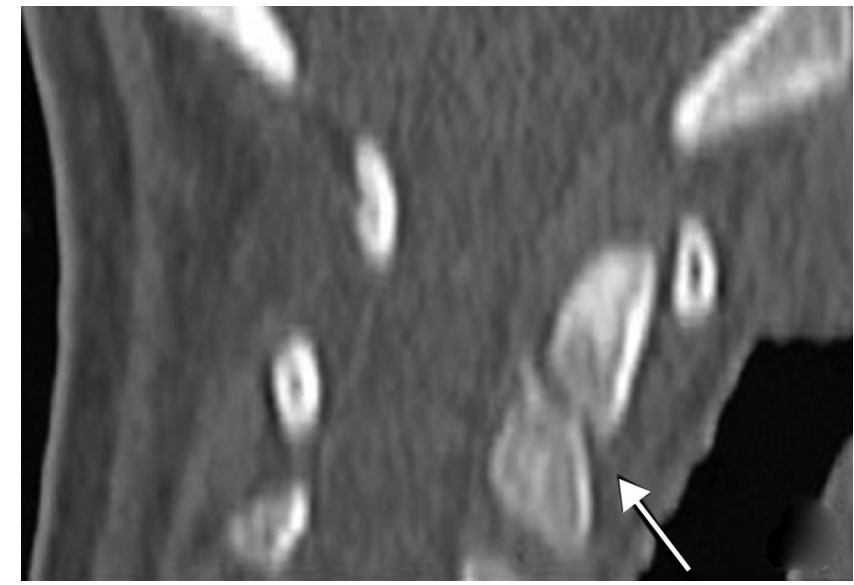

Fig. $2 b$

a) Lateral radiographs of the cervical spine showing minimal evidence of an odontoid fracture. b) Sagittal CT reconstructions show a type-IA fracture (arrow).

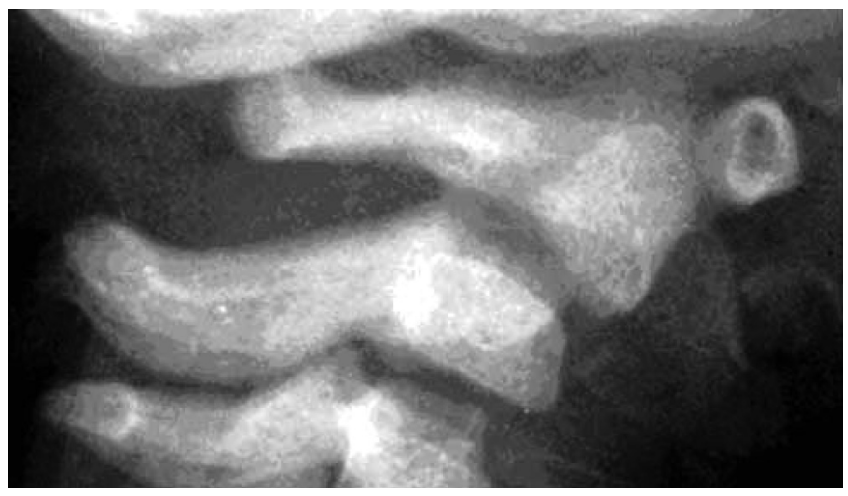

Fig. 3

Lateral radiograph of the cervical spine showing a type-IB fracture.

underwent surgical stabilisation and fusion at a later date. In case 14 the spinal-cord injury occurred at C1-2 and the child died from severe head injuries four days after admission. In the open synchondrosis group, the association of odontoid fracture-dislocation with injury to the spinal cord was seen only in those under two years of age ( 2 of 4 patients). This difference was significant $(\mathrm{p}=0.04)$.

The associated injuries in individual patients within the open synchondrosis group are summarised in Table I.

On the basis of our findings, we defined four types of fracture pattern (Fig. 1) as follows. Type I consisted of odontoid fractures at the level of the synchondrosis. These were subdivided into type IA, fracture of the synchondrosis with displacement of less than $10 \%$ and normal plain radiographs (4 cases) (Fig. 2); type IB, fracture of the synchondrosis with displacement of $10 \%$ to $100 \%$ (8 cases) (Fig. 3) and type IC, fracture of the synchondrosis with dis-

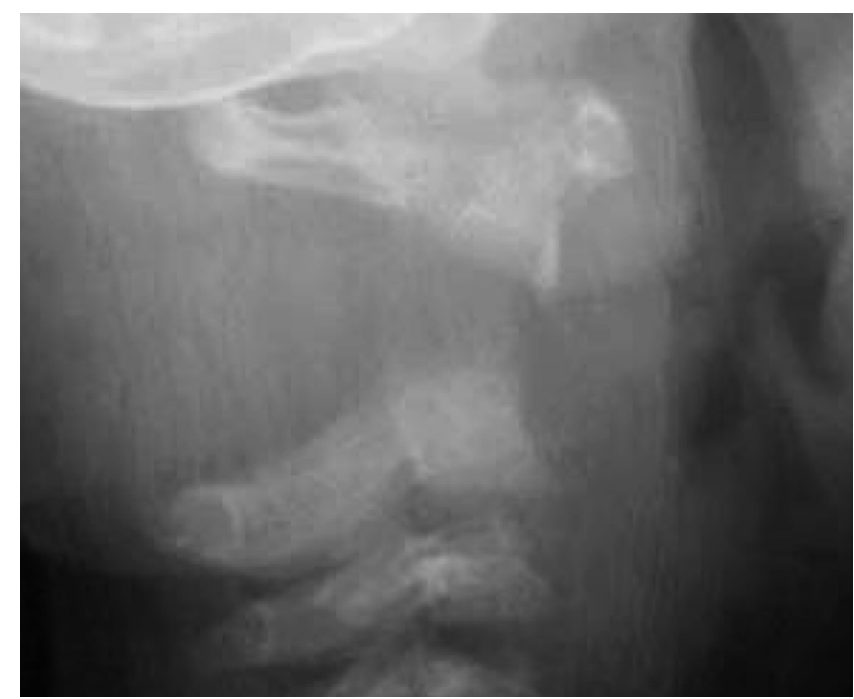

Fig. 4

Lateral radiograph showing a type-IC fracture.

placement of more than $100 \%$ ( 2 cases) (Fig. 4). Type II consisted of odontoid fractures above the level of synchondrosis (3 cases) (Fig. 5).

Table $\mathrm{V}$ gives details of the management of the 17 patients with an open synchrondosis. Nine were immobilised in a Halo body jacket (PMT Corporation, Charhassen, Minnesota) and seven in a Minerva orthosis (Boston Brace International, Avon, Massachusetts). The mean stay in hospital for all 17 patients was 8.7 days $(0$ to 21). One patient (case 14) died in hospital from severe head injuries prior to immobilisation. Another was lost to follow-up after six weeks. The mean follow-up for the remaining 15 patients was 2.33 years (1.3 to 7.2 ). 


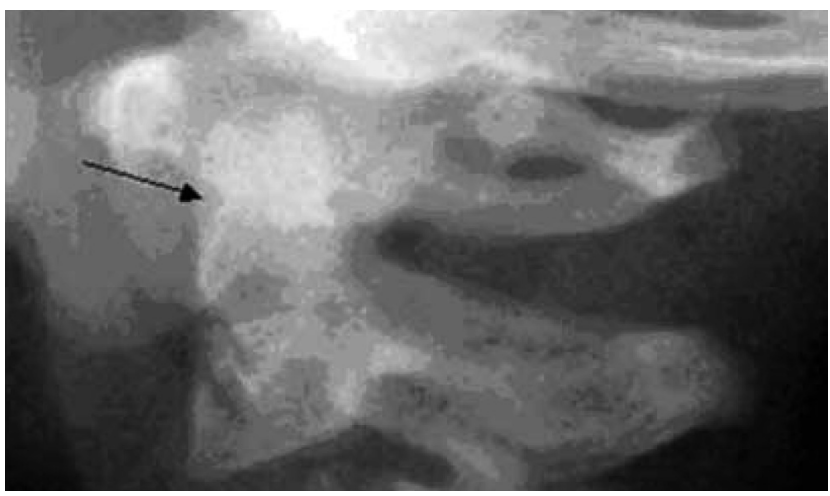

Fig. $5 a$

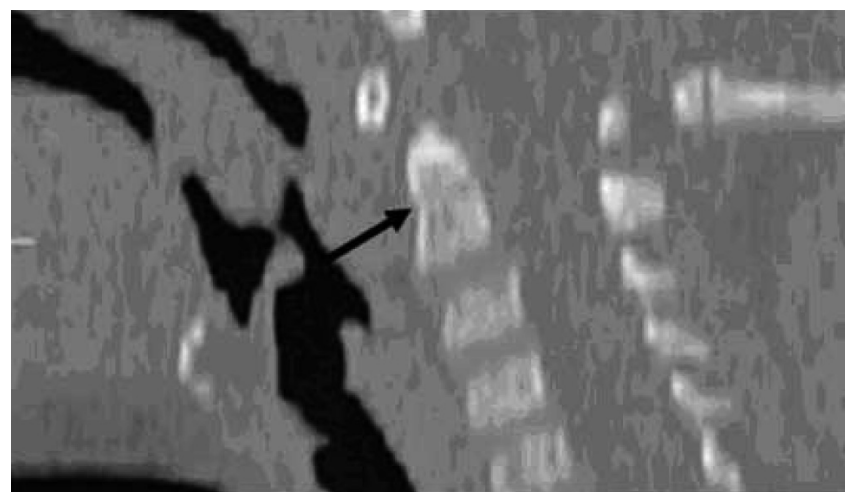

Fig. $5 b$

a) Lateral radiograph of the cervical spine showing subtle evidence (black arrow) of a type-Il fracture. b) Sagittal CT reconstruction shows conclusively the presence of a type-Il fracture (black arrow).

Table V. Management of the 17 patients with an odontoid fracture and an open synchondrosis with immobilisation in a Halo body jacket

\begin{tabular}{ll}
\hline Type \\
\hline IA (4 cases) & $\begin{array}{l}\text { All underwent successful in situ immobilisation in a Halo body jacket or Minerva orthosis } \\
\text { IB (8 cases) }\end{array}$ \\
$\begin{array}{l}\text { Closed reduction in extension. One patient (case 17) displaced and underwent atlantoaxial fusion } \\
\text { One patient (case 16) died as a result of extensive head injuries. A second underwent immobilisation in a Halo } \\
\text { body jacket with atlantoaxial fusion }\end{array}$ \\
II (3 cases) & All underwent successful in situ immobilisation in a Halo body jacket or Minerva orthosis
\end{tabular}

Their treatment is summarised in Table V and their outcome in Table II.

Patients with a closed basilar synchondrosis. There were three boys and three girls with a mean age of 13.6 years (10.70 to 15.89$)$. Their presenting symptoms and associated injuries are given in Table III. Importantly, three also had concomitant brain injuries. In contrast to the group with an open basilar synchondrosis, there was no delay in establishing the diagnosis.

All the fractures in this group could be classified by the system of Anderson and D'Alonzo ${ }^{13}$ for adult patients. There were more associated fractures in the group with a closed synchondrosis. In the open synchondrosis group, only five of the 17 patients had associated fractures, compared with five of the six patients in the closed group ( $\mathrm{p}=0.03)$.

Comparison of the groups. Although the numbers in our study are small and limit statistical analysis, there was a trend towards a lower incidence of traumatic brain injuries ( 2 of $17 v s 3$ of 6), more missed or delayed diagnoses ( 6 of 17 $v s$ of 6 ) and a shorter mean hospital admission ( 8.7 days $v$ s 16.33 days) in the group with an open synchondrosis.

\section{Discussion}

From our analysis of odontoid fractures in children we were able to develop a classification system for children with an open basilar synchondrosis which has potential advantages for diagnosis and management. This classification was based on the degree of displacement and the relationship of the fracture line to the basilar synchondrosis with four characteristic fracture patterns which comprehensively covers all the fractures (Fig. 1).

Using this classification, the most reported fractures of the synchondrosis are type IB. In their series, Sherk et $\mathrm{al}^{16}$ reported 11 patients, of whom four had completely displaced and seven partially displaced fractures. Odent et $\mathrm{al}^{9}$ in a series of 15 patients, reported 13 fractures of the synchondrosis with anterior displacement between $10 \%$ and $100 \%$. Type-IA fractures have been described infrequently, perhaps because of the difficulty in establishing the diagnosis on plain radiographs. However, several studies have reported undisplaced odontoid fractures. ${ }^{9,11,19,20}$ Although rare, fractures which we have classified as type IC and type II have also been reported. ${ }^{8,10,13,15,17,21}$ Finally, there have been a small number of reports of odontoid fractures with posterior displacement. ${ }^{9,11}$ While we have not seen any of this type, we believe that they should be classified and treated in the same way as fractures with anterior displacement.

We recommend additional imaging, preferably a CT with sagittal and coronal reconstructions in all patients in whom an odontoid fracture is suspected in order to detect type-IA and type-II fractures. Our study has shown that for patients with normally appearing plain radiographs and a history of high-energy trauma, CT with reconstructions may be indicated (Figs 2 and 5). If the diagnosis remains elusive or if 


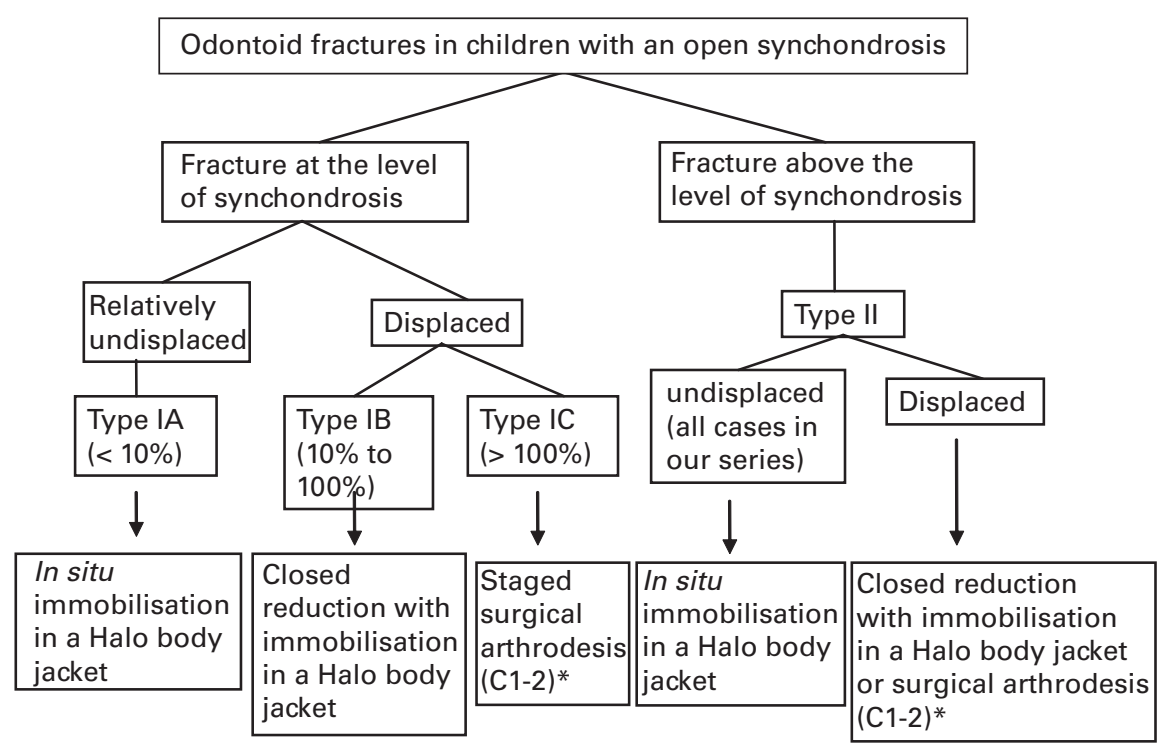

Fig. 6

Algorithm for the management of odontoid fractures in children with an open synchondrosis (*atlantoaxial arthrodesis).

the patient has neurological symptoms, MRI which shows high signal in the odontoid is likely to be diagnostic of a fracture. Further, because of the risk of causing additional injury by taking flexion/extension views, we prefer to examine the soft tissues for high signal using MRI, particularly in the presence of an associated neurological problem such as a head injury. We note that in two of the three cases of type-II fractures reported in the literature, the diagnosis was initially missed and advanced imaging techniques were required to diagnose the fracture. ${ }^{8,10}$ For patients with a type-IB or type-IC fracture, plain lateral radiographs should be sufficient to make the diagnosis (Figs 3 and 4).

While there is no evidence to suggest that MRI is of help in making the diagnosis, it has been shown to be of value in excluding odontoid fractures. ${ }^{3}$ It has also been shown to give useful additional information in children with associated neurological injuries. ${ }^{9}$ Finally, at least one series has been reported which confirms our finding that in patients with type-II fractures, MRI may show signal change both at the synchondrosis and above at the level of the fracture. ${ }^{10}$

Based on our classification system we propose an algorithm for the treatment of odontoid fractures in patients with an open synchondrosis (Fig. 6). Our success rate of $87 \%$ using closed reduction and immobilisation is comparable with that of other large series in which it ranges from $80 \%$ to $100 \%{ }^{9,15,16}$ For patients with type-IC fractures we recommend a staged fusion comprising initial stabilisation in a Halo body jacket followed by early surgical stabilisation.

In our series there were two cases of injury to the spinal cord in children aged less than two years. Based on this experience and a small number of reports of injury to the spinal cord in other large series, ${ }^{13,15,16,19,22}$ we believe that the isolated odontoid fracture in childhood is not usually associated with a significant spinal-cord injury. Transient neurological signs and symptoms such as paraesthesiae and weakness have been reported, but are rare. ${ }^{9,15,19,23}$

We saw no odontoid fractures in children between the age of seven and 11 years. A number of other authors have made a similar observation. ${ }^{24-26}$ We believe that there are three patterns of injury which depend on the age at which the child is injured. Younger children with an open synchondrosis usually have a fracture through it whereas children over the age of 11 years sustain fractures which follow the adult pattern. Injuries which occur between the age of seven and 11 years are probably of a different type. We agree with Lui et $\mathrm{al}^{26}$ who observed that children in this age group with a fused synchondrosis are more likely to present with disruption of the atlantoaxial ligament or atlanto-occipital dislocation. In their series of 22 children, all of whom were under the age of 18 years, they noted two cases of odontoid fracture in children under six years and 11 cases in children over 13 years of age. However, between the age of seven and 12, there were only two children with an odontoid fracture while seven had an atlantoaxial dislocation without an associated fracture. It appears that more force is needed to cause an odontoid fracture through bone than to cause a fracture through the synchondrosis. It is not clear why children between the age of seven and 12 years sustain ligament disruptions more often than odontoid fractures.

Based on our data, it appears that, by comparison with children with a closed synchondrosis, odontoid fractures in children with an open basilar synchondrosis are more likely to be isolated injuries. They are harder to diagnose and are 
more likely to be missed, but heal well with treatment in a Halo body jacket.

The limitation of our study was that the number of children treated was relatively small and the series was therefore underpowered. However, given that this is a relatively rare injury in children, we believe that our observations are helpful and our conclusions valid. Despite this limitation, our study represented a first step towards the establishment of a useful classification for odontoid fractures in children.

We wish to thank J. Goebel, Children's Hospital of Philadelphia, Pennsylvania, USA.

No benefits in any form have been received or will be received from a commercial party related directly or indirectly to the subject of this article.

\section{References}

1. McGrory BJ, Klassen RA. Arthrodesis of the cervical spine for fractures and dislocations in children and adolescents: a long-term follow-up study. J Bone Joint Surg [Am] 1994;76-A:1606-16.

2. Copley LA, Dormans JP. Cervical spine disorders in infants and children. J Am Acad Orthop Surg 1998;6:204-14.

3. Flynn J. Spine trauma in the pediatric population. Spine 2001;14:249-61.

4. Alp MS, Crockard HA. Late complication of undetected odontoid fracture in children. BMJ 1990;300:319-20.

5. Amyes EW, Anderson FM. Fracture of the odontoid process: report of sixty-three cases. AMA Arch Surg 1956;72:377-93.

6. Fielding JW, Griffin PP. Os odontoideum: an acquired lesion. J Bone Joint Surg [Am] 1974;56-A:187-90.

7. Freiberger RH, Wilson PD Jr, Nicholas JA. Acquired absence of the odontoid process: a case report. J Bone Joint Surg [Am] 1965;47-A:1231-6.

8. Mazur JM, Loveless EA, Cummings RJ. Combined odontoid and jefferson fracture in a child: a case report. Spine 2002;27:197-9.

9. Odent T, Langlais J, Glorion C, et al. Fractures of the odontoid process: a report of 15 cases in children younger than 6 years. J Pediatr Orthop 1999;19:51-4.
10. Schippers N, Konings P, Hassler W, Sommer B. Typical and atypical fractures of the odontoid process in young children: report of two cases and a review of the literature. Acta Neurochir (Wien) 1996;138:524-30.

11. Fujii E, Kobayashi K, Hirabayashi K. Treatment in fractures of the odontoid process. Spine 1988;13:604-9.

12. Vining DJ, Benzel EC, Orrison W. Childhood odontoid fractures evaluated with computerized tomography: case report. J Neurosurg 1992;77:795-8.

13. Anderson LD, D'Alonzo RT. Fractures of the odontoid process of the axis. J Bone Joint Surg [Am]1974;56-A:1663-74.

14. Uemara K, Matsumara A, Noguchi S, et al. Posterior fusion for odontoid fracture in an infant: case report. Neurol Med Chir (Tokyo) 1996;36:175-8.

15. Mandabach M, Ruge JR, Hahn YS, McLone DG. Pediatric axis fractures: early halo immobilization, management and outcome. Pediatr Neurosurg 1993;19:225-32.

16. Sherk HH, Nicholson JT, Chung SM. Fractures of the odontoid process in young children. J Bone Joint Surg [Am] 1978;60-A:921-4

17. Godard J, Hadji M, Raul JS. Odontoid fractures in the child with neurological injury: direct anterior osteosynthesis with a cortico-spongious screw and literature review. Childs Nerve Syst 1997;13:105-7.

18. No authors listed. International classification of diseases (ICD). http:// www.who.int/classifications/icd/en (date last accessed 1 May 2009).

19. Connolly B, Emery D, Armstrong D. The odontoid synchondrotic slip: an injury unique to young children. Pediatr Radiol 1995;25(Suppl 1):129-33.

20. Seimon LP. Fracture of the odontoid process in young children. J Bone Joint Surg [Am] 1977;59-A:943-8.

21. Bohn D, Armstrong D, Becker L, Humphreys R. Cervical spine injuries in children. J Trauma 1990:30:463-9.

22. Gropper P, Peerless S, Morton K. Odontoid fractures in children. J Bone Joint Surg [Br] 1975;33-B(Suppl):434-5.

23. Griffiths SC. Fracture of odontoid process in children. J Pediatr Surg 1972;7:680-3.

24. Apple JS, Kirks R, Merten DF, Martinez S. Cervical spine fractures and dislocations in children. Pediatr Radio/ 1987;17:45-9.

25. Evans DL, Bethem D. Cervical spine injuries in children. J Pediatr Orthop 1989;9:563-8.

26. Lui TN, Lee ST, Wong CW, et al. C1-C2 fracture-dislocations in children and adolescents. J Trauma 1996;40:408-11.

27. No authors listed. Glasgow Coma Score. http://www.sfar.org/scores2/ glasgow2.html. (date last accessed 1 May 2009). 